\title{
The silver man: a rare cosmetic complication of alternative medicine
}

\author{
Lovely Chhabra, Pooja Sareen, Nitin Trivedi
}

Department of Internal Medicine, Saint Vincent Hospital, University of Massachusetts Medical School, Worcester, Massachusetts, USA

\section{Correspondence to} Dr Lovely Chhabra, lovids@hotmail.com
To cite: Chhabra L, Sareen P, Trivedi N. BMJ Case Rep Published online: [please include Day Month Year] doi:10.1136/bcr-2013009728

\section{DESCRIPTION}

A 58-year-old man with a medical history of schizoaffective disorder, delusional parasitosis and clostridium difficile colitis (CDC) was hospitalised for worsening diarrhoea, as a result of CDC exacerbation. His physical examination revealed normal vital signs and a bluish-grey pigmentation of the skin and nailbeds (figure 1). The patient firmly believed that he had Morgellons disease (a form of delusional parasitosis). In the past, he had seen several physicians including psychiatrists to seek treatment for his delusional parasitosis. The patient reported that he had been using oral silver colloidal solution for several months, in order to purify his blood and kill the (delusional) parasites, which he believed were present in his skin and stool. $\mathrm{He}$ got introduced to this remedy through the internet. Review of his prior medical records revealed a negative diagnostic workup for Addison's disease and haemochromatosis, but a positive skin biopsy confirming the diagnosis of argyria.

Argyria is a rare disorder associated with the exposure or ingestion of silver compounds resulting in a permanent dermal deposition of inert silver salts and has no effective medical treatment. ${ }^{1}{ }^{2}$ Unfamiliarity to this disorder may often result in a clinical misdiagnosis prompting unnecessary further work-up. Common disease conditions which may mimic argyria are cyanosis, Addison's disease, haemochromatosis, Wilson's disease, Ochronosis and methaemoglobinemia. ${ }^{1-3}$ Skin biopsy revealing silvery granule deposits is considered a gold standard for the diagnosis of argyria, however is rarely required, as the clinical history and physical
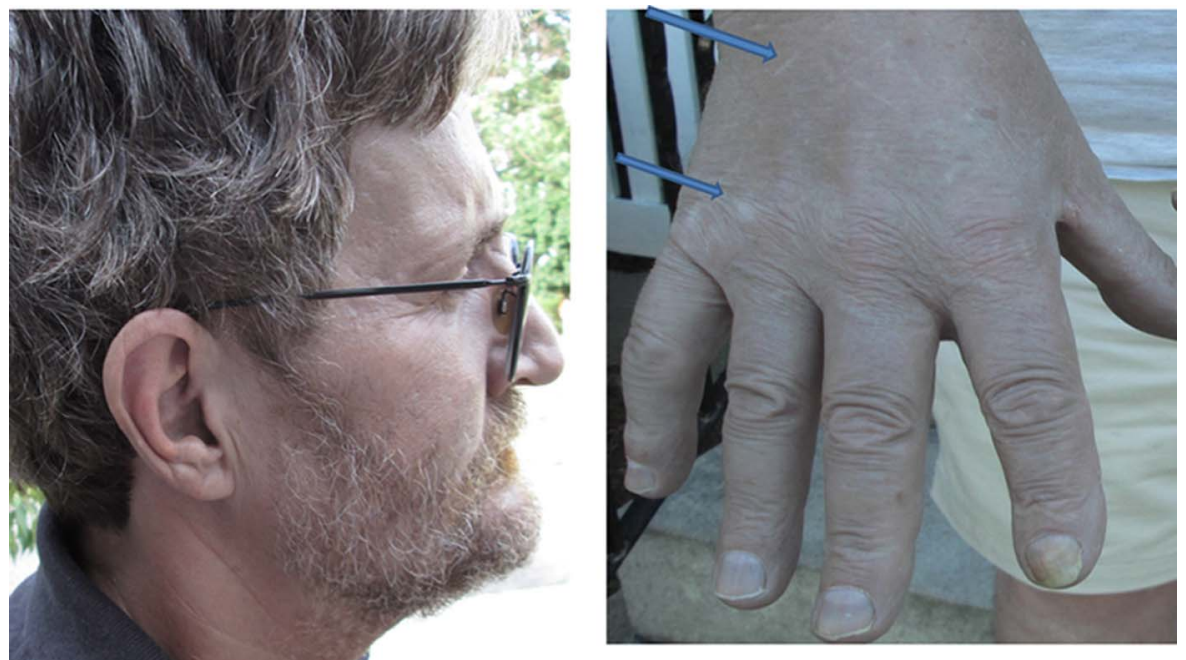

Figure 1 Demonstrates silver-grey discolouration of the face and nail beds. Multiple small scratches on his skin of the dorsal surface of his hands are seen (marked with arrows). These scratches were self-inflicted by the patient, and he firmly believed these to be secondary to a skin infestation of some parasites (Morgellons syndrome). examination findings (including skin examination under fluorescent X-ray) are considered sufficient in routine practice. The general population needs more awareness regarding the use of fraudulent remedies marketed through the internet claiming their effectiveness against various medical ailments.

\section{Learning points}

- Argyria is a rare disorder associated with the exposure or ingestion of silver compounds.

- This diagnosis should be suspected in patients with silver grey discolouration and who have underlying psychiatric illness and report ingestion to a silver compound or undefined alternative medicine. Unfamiliarity to this disorder may often unnecessary further workup.

- No effective medical treatment is available. Dermabrasion has been tried with variable success.

Contributors All authors have significantly contributed in writing this manuscript and reviewing the literature. All authors have reviewed and approved the final manuscript.

\section{Competing interests None.}

Patient consent Obtained.

Provenance and peer review Not commissioned; externally peer reviewed. result in a clinical misdiagnosis prompting 


\section{REFERENCES}

1 White JM, Powell AM, Brady K, et al. Severe generalized argyria secondary to ingestion of colloidal silver protein. Clin Exp Dermatol 2003;28:254-6.
2 Wickless SC, Shwayder TA. Medical mystery-the answer. N Engl J Med 2004;351:2349-50.

3 Kwon $\mathrm{HB}$, Lee $\mathrm{JH}$, Lee $\mathrm{SH}$, et al. A case of argyria following colloidal silver ingestion. Ann Dermatol 2009;21:308-10.

Copyright 2013 BMJ Publishing Group. All rights reserved. For permission to reuse any of this content visit

http://group.bmi.com/group/rights-licensing/permissions.

BMJ Case Report Fellows may re-use this article for personal use and teaching without any further permission.

Become a Fellow of BMJ Case Reports today and you can:

- Submit as many cases as you like

- Enjoy fast sympathetic peer review and rapid publication of accepted articles

- Access all the published articles

- Re-use any of the published material for personal use and teaching without further permission

For information on Institutional Fellowships contact consortiasales@bmjgroup.com

Visit casereports.bmj.com for more articles like this and to become a Fellow 